OPEN ACCESS

Edited by:

Timo Kirschstein,

University of Rostock, Germany

Reviewed by:

Luiz E. Mello,

Federal University of

São Paulo, Brazil

Carola A. Haas,

Albert Ludwigs Universität

Freiburg, Germany

*Correspondence:

Steve C. Danzer

steve.danzer@cchmc.org

Specialty section: This article was submitted

to Epilepsy,

a section of the journal

Frontiers in Neurology

Received: 29 January 2018 Accepted: 17 April 2018

Published: 03 May 2018

Citation:

Godale CM and Danzer SC (2018)

Signaling Pathways and

Cellular Mechanisms Regulating

Mossy Fiber Sprouting in the

Development of Epilepsy.

Front. Neurol. 9:298.

doi: 10.3389/fneur.2018.00298

\section{Signaling Pathways and Cellular Mechanisms Regulating Mossy Fiber Sprouting in the Development of Epilepsy}

\author{
Christin M. Godale ${ }^{1,2}$ and Steve C. Danzer $r^{1,2,3,4 *}$ \\ ${ }^{1}$ Department of Anesthesia, Cincinnati Children's Hospital Medical Center, Cincinnati, OH, United States, ${ }^{2}$ Neuroscience \\ Graduate Program, University of Cincinnati, Cincinnati, $\mathrm{OH}$, United States, ${ }^{3}$ Department of Anesthesia, University of \\ Cincinnati, Cincinnati, $\mathrm{OH}$, United States, ${ }^{4}$ Department of Pediatrics, University of Cincinnati, Cincinnati, OH, United States
}

The sprouting of hippocampal dentate granule cell axons, termed mossy fibers, into the dentate inner molecular layer is one of the most consistent findings in tissue from patients with mesial temporal lobe epilepsy. Decades of research in animal models have revealed that mossy fiber sprouting creates de novo recurrent excitatory connections in the hippocampus, fueling speculation that the pathology may drive temporal lobe epileptogenesis. Conducting definitive experiments to test this hypothesis, however, has been challenging due to the difficulty of dissociating this sprouting from the many other changes occurring during epileptogenesis. The field has been largely driven, therefore, by correlative data. Recently, the development of powerful transgenic mouse technologies and the discovery of novel drug targets has provided new tools to assess the role of mossy fiber sprouting in epilepsy. We can now selectively manipulate hippocampal granule cells in rodent epilepsy models, providing new insights into the granule cell subpopulations that participate in mossy fiber sprouting. The cellular pathways regulating this sprouting are also coming to light, providing new targets for pharmacological intervention. Surprisingly, many investigators have found that blocking mossy fiber sprouting has no effect on seizure occurrence, while seizure frequency can be reduced by treatments that have no effect on this sprouting. These results raise new questions about the role of mossy fiber sprouting in epilepsy. Here, we will review these findings with particular regard to the contributions of new granule cells to mossy fiber sprouting and the regulation of this sprouting by the mTOR signaling pathway.

Keywords: mTOR, phosphatase and tensin homolog/PI3K/Akt, adult neurogenesis, dentate granule cell, epileptogenesis

Granule cells of the hippocampal dentate gyrus possess unique axonal projections known as mossy fibers. In healthy animals, mossy fibers produce numerous collaterals in the dentate hilus, which innervate mossy cells and hilar interneurons before projecting into stratum lucidum of the CA3 pyramidal cell layer, where they innervate interneurons (1) and the apical and basal dendrites of CA3 pyramidal cells (2). Recent work has also revealed that granule cells contact CA2 pyramidal cells, a population previously believed to be devoid of mossy fiber input (3-5). In laboratory animals modeling mesial temporal lobe epilepsy (mTLE), mossy fiber axon reorganization can occur in all of the hippocampal subfields normally targeted by granule cells (6-12). In addition to their normal 
projections, however, granule cell axons add an additional target to their repertoire: the inner molecular layer of the dentate gyrus (13-18). The dentate molecular layer contains the apical dendrites of the granule cells and is subdivided into inner, middle, and outer regions. Portions of the dendritic tree in the middle and outer molecular layers ( $\mathrm{oml}$ ) are innervated by afferents from entorhinal cortex. Axons from lateral entorhinal cortex favor the oml, while medial entorhinal cortex favors the middle $(19,20)$. The inner molecular layer contains the proximal-most portion of the granule cell dendritic trees, which are innervated by hilar interneurons, mossy cells, and commissural fibers $(21,22)$.

In the hippocampus, granule cell mossy fiber axons sprout, projecting new collaterals to the inner molecular layer, where they form excitatory synaptic connections with the proximal portions of the granule cell dendritic trees $(23,24)$. Mossy fiber sprouting is not indiscriminate, however, as the granule cell axons form a dense plexus of fibers in the inner molecular layer, but often avoid immediately adjacent regions like the granule cell body layer and the middle molecular layer. Co-occurring granule cell dispersion, in which the granule cell bodies spread into the molecular layer, does reduce this specificity. When robust dispersion is present, sprouted mossy fibers also target granule cell somas (25-27). The mechanisms regulating the specificity of mossy fiber sprouting have yet to be elucidated.

\section{FUNCTIONAL SIGNIFICANCE OF MOSSY FIBER SPROUTING IN EPILEPSY}

Epilepsy is hypothesized to occur as a consequence of persistent changes in brain structure and function that create a propensity for spontaneous recurrent seizures (28). A key goal of epilepsy research, therefore, is to identify and understand the specific brain changes responsible for the disease. Mossy fiber sprouting "rewires" the epileptic hippocampus, creating recurrent excitatory circuits (24). The creation of this de novo pro-excitatory circuit, combined with its consistent appearance in humans and laboratory animals with mTLE, has led to an intense field of study aimed at determining whether mossy fiber sprouting plays a causal role in the disease.

Although mossy fiber sprouting is one of the most frequently observed changes in mTLE, the degree of sprouting varies considerably among laboratory animals and humans, ranging from extensive to undetectable (29). Schmeiser et al. (30), for example, observed no sprouting in $18 \%$ of patients with mTLE. The epilepsies include a complex array of dozens of identified disorders (31), so it is not a huge surprise that no single pathology is universally present, even within the sub-classification of mTLE. Furthermore, the absence of sprouting in some patients with mTLE clearly demonstrates that, at best, mossy fiber sprouting can only be relevant to a subset of patients with the condition, and is not required for the development of the disorder. Use of animal models has made it possible delve deeper into the relationship between sprouting and epilepsy, with investigators asking whether a positive correlation exists between the degree of sprouting and epilepsy severity. While many studies have revealed positive correlations, others have not (24). The circumstantial evidence linking mossy fiber sprouting to epilepsy, therefore, is ambiguous. One possible reason for inconsistent results is that mossy fiber sprouting is just one of the many pathologies that contribute to epilepsy. Hester and Danzer (32), for example, found that sprouting did positively correlate with seizure frequency in the rodent pilocarpine model of epilepsy. They also found, however, that positive correlations were even stronger when multiple pathologies were considered. This finding favors an "a la carte" model of epileptogenesis, in which epilepsy can be produced through different combinations of pathologies. If correct, sprouting may play a critical role in one patient, but be absent from another-even though both exhibit similar seizure phenotypes.

\section{CONTRIBUTIONS OF NEWLY GENERATED AND MATURE GRANULE CELLS TO MOSSY FIBER SPROUTING}

Unlike the majority of neurons in the brain, dentate granule cells continue to proliferate throughout life in laboratory animals (33). Adult neurogenesis also appears to occur in humans $(34,35)$, although this conclusion is controversial (36). If neurogenesis does continue in adult humans, a population of neurons that differs considerably by age will result. These age differences are functionally significant, as young granule cells in rodents (4-6 weeks) exhibit morphological and physiological properties that are distinct from older cells (37-40). The impact of cell-age differences is also evident in epilepsy, where newborn granule cells are more likely to exhibit epilepsy-associated pathologiessuch as misplacement to ectopic locations or formation of aberrant hilar-projecting basal dendrites-relative to adult granule cells (41-47). Notably, while discerning whether adult neurogenesis occurs in adult humans will take time and additional studies to resolve, mossy fiber sprouting and other granule cell abnormalities are clearly present in people with mTLE. These pathologies, therefore, will remain relevant regardless of their cellular origins.

The relationship between granule cell age and whether or not the cell contributes to mossy fiber sprouting has taken considerable effort to decipher. Initial studies clearly revealed that newborn granule cells contribute to mossy fiber sprouting (41), but numerous follow-up studies were required to establish that their contribution follows a complex temporal dynamic $(44,48,49)$. Specifically, while some granule cell abnormalities, such as basal dendrites and ectopic localization, become evident before the newborn cells reach maturity (50-55), mossy fiber sprouting does not appear until the cells are functionally mature: about four weeks of age. The age range of granule cells that can contribute to mossy fiber sprouting is also broader than the range for other abnormalities. While ectopic cells originate almost exclusively from cells born after the epileptogenic insult, cells up to 7 weeks old at the time of the insult can contribute to mossy fiber sprouting (11). The broader age range of contributing cells, and the apparent requirement for cells to reach maturity before their axons begin to sprout, creates an age-gradient among the cells that underlie sprouting. The oldest cells (7 weeks) contribute first, with axons from these 
neurons appearing in the inner molecular layer within 2 weeks of the insult, while the axons of younger cells do not appear until 4 weeks after the insult.

The delayed development of mossy fiber sprouting by newborn granule cells is something of a surprise. This is because the delay does not reflect an inability of immature granule cells to produce an axon. Axogenesis begins within 4 days of granule cell birth (56), and axons reach stratum lucidum of CA3a-the distal-most region of CA3-by 12 days $(57,58)$. For a mossy fiber axon to reach $\mathrm{CA} 3 \mathrm{a}$, it must grow hundreds of microns further than would be needed to reach the inner molecular layer. Immature granule cells, therefore, are capable of extending axons significant distances, raising the question of why extension to the inner molecular layer is delayed till maturity. One plausible explanation is that immature cells are unresponsive to signals that induce mossy fiber sprouting among their more mature siblings. Examination of signaling molecules expressed at the transition from immature to mature stages could be a fruitful avenue for future studies.

\section{IMPACT OF ABLATING NEWBORN CELLS ON MOSSY FIBER SPROUTING}

Advances in technology have made it possible to selectively manipulate newborn granule cells in the epileptic hippocampus to assess their role in epilepsy. In the first of these studies, Cho and colleagues (59) generated transgenic mice expressing the cell-killing gene thymidine kinase in granule cell progenitors. When they used these transgenic mice to block adult neurogenesis in the mouse pilocarpine model it significantly reduced spontaneous seizure frequency, but had no effect on the extent of mossy fiber sprouting. Similarly, Hosford and colleagues $(60,61)$ used a diphtheria-toxin receptor expression strategy to ablate newborn granule cells either days or months after pilocarpine epileptogenesis. Treatments reduced seizure occurrence by about 50\%, but neither reduced mossy fiber sprouting (Figure 1). This dissociation raises questions about whether mossy fiber sprouting plays an important role in regulating seizure occurrence in epilepsy.

The absence of an effect of newborn cell ablation on the degree of mossy fiber sprouting was unexpected. The newborn granule cells eliminated have been shown to contribute to sprouting, so some reduction was predicted. Indeed, other measures of aberrant neurogenesis, like ectopic cell numbers, were reduced in all three studies (59-61). Explanations for the absence of an effect on sprouting include the possibility that the contribution of newborn cells is less than predicted, or that surviving cells compensate by increasing their level of sprouting. In the ablation experiments conducted to date, the interval between ablation and final analysis was several months, providing a window for compensatory cell growth to occur. Compensatory sprouting would also be consistent with the suggestion by Buckmaster (62) that homeostatic mechanisms act to maintain a target level of granule cell innervation in the brain, such that loss of recurrent input by ablation would induce surviving cells to replace that input. In either case, however, significant anti-epileptogenic effects can be achieved in the absence of reduced mossy fiber sprouting.

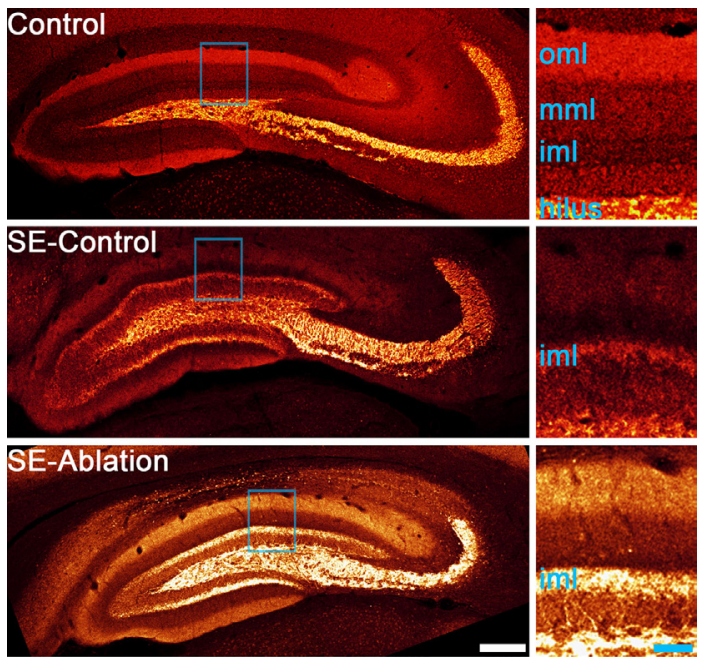

FIGURE 1 | Confocal maximum projections showing mossy fiber axons labeled with zinc transporter-3 (red). A control animal and two epileptic animals are shown. Tissue from epileptic animals was collected about 5 months after pilocarpine-induced status epilepticus (SE). The epileptic animal shown in the middle panel received a control ablation treatment (SE-control), while newborn granule cells were ablated from the epileptic animal in the lower panel 1 month before tissue collection (SE-ablation). Regions highlighted in blue in each image are shown enlarged in the right panels. Both SE animals show mossy fiber sprouting in the inner molecular layer (iml), while the control animal did not. Newborn granule cell ablation reduced seizure frequency by about $50 \%$, but had no effect on mossy fiber sprouting (61). Abbreviations: oml, outer molecular layer; $\mathrm{mml}$, middle molecular layer. Scale bars $=200 \mu \mathrm{m}$ (left) and $50 \mu \mathrm{m}$ (right).

\section{REGULATION OF MOSSY FIBER SPROUTING BY MTOR}

The mechanistic (previously referred to as mammalian) target of rapamycin (mTOR) pathway has recently emerged as a promising target for anti-epileptogenesis therapies, and studies with mTOR antagonists provide some novel insights into the significance of mossy fiber sprouting. The mTOR pathway regulates neuronal survival, growth, and plasticity. In addition, the pathway becomes hyperactive following epileptogenic brain injury in animal models and in humans with epilepsy (63-65). In addition, many investigators have found that inhibition of the pathway with mTOR antagonists can reduce the incidence of spontaneous seizures in epileptic animals (66-71), although others have found no effect $(72-75)$. The effects outlast the periods of drug exposure, indicative of disease-modifying, rather than acute anticonvulsant, properties (76). Evidence of diseasemodifying effects raised the possibility that mTOR antagonism might mitigate pathological brain changes that mediate epileptogenesis, so naturally investigators assessed mossy fiber sprouting. Zeng and colleagues (66) observed reduced mossy fiber sprouting in the rodent kainic acid model of epilepsy when the animals were treated with the mTOR antagonist rapamycin; a finding replicated by numerous other groups using multiple epilepsy models $(67-69,71,77-79)$. Direct infusion of rapamycin into the hippocampus also blocked sprouting locally around the infusion site (80). Notably, however, rapamycin 
can reduce mossy fiber sprouting without impacting seizures. Systemic treatment with rapamycin in the pilocarpine model of epilepsy blocked mossy fiber sprouting, but had no effect on seizure frequency $(72,74)$ or interictal spikes (81). Rapamycin was also ineffective at blocking paroxysmal discharges in the intrahippocampal kainic acid model of epilepsy, but did block mossy fiber sprouting (75). These findings are reminiscent of work begun decades ago, when it was found that treatment with the protein synthesis inhibitor cycloheximide could block mossy fiber sprouting, but not seizures in the rodent kainic acid and pilocarpine models (82-84). Although the efficacy of cycloheximide is controversial $(85,86)$, the finding that seizures can be dissociated from mossy fiber sprouting is not. Zhu et al. (87), for example, used the antineurogenic agent methylazoxymethanol acetate to reduce sprouting in the rodent pilocarpine model, but this had no effect on behavioral seizure frequency. Viewed in toto, therefore, rapamycin has consistently been shown to block mossy fiber sprouting, strongly implicating excess mTOR signaling in the process. Correlated reductions in mossy fiber sprouting and seizure frequency, however, occur in some cases but not in others, suggesting that sprouting may be an epiphenomenon, rather than a cause of mTLE.

Analyses of transgenic animals with granule cell-specific hyperactivation of the mTOR pathway provide additional insights into the role of mTOR signaling in sprouting. Granule cell-specific hyperactivation of mTOR signaling has been achieved by deleting phosphatase and tensin homolog (PTEN) from granule cell progenitors and immature granule cells using tamoxifen-inducible Nestin-CreER ${ }^{\mathrm{T} 2}$, Gli1-CreER ${ }^{\mathrm{T} 2}$, and Pomc-Cre transgenic mice (88-90). PTEN acts as a negative regulator of the mTOR pathway, while the different promotors can be used to target PTEN deletion to postnatally generated granule cells. Deletion of PTEN from 2- to 4-week-old mice produces epilepsy in Nestin- and Gli1-Cre lines $(88,89)$. PTEN deletion leads to granule cell mossy fiber axon abnormalities, with evidence for increased axon collateralization in the hilus and stratum lucidum (91) and the development of recurrent excitation in acute hippocampal slices $(92,93)$. Epilepsy can develop in these animals, however, without robust mossy fiber sprouting (89). Sprouting does occur (Figure 2), but only in a subset of animals, demonstrating that sprouting is not essential for recurrent seizures in this model. Moreover, the degree of sprouting followed an "all or none" pattern, with some animals exhibiting extensive sprouting, and others essentially none (89). This result is interesting, because the percentage of granule cells lacking PTEN covered a broad range in this study: from 1 to $25 \%$. If PTEN loss-and subsequent mTOR hyperactivation-leads to the direct, cell-intrinsic, induction of mossy fiber sprouting, one would predict a graded effect, with the degree of sprouting increasing gradually with the percentage of knockout cells. The absence of a graded increase implies that hyperactivation of the mTOR pathway is not sufficient to induce mossy fiber sprouting. Rather, the findings suggest some other factor is abruptly engaged once the animals reach deletion rates of about 15\% (Figure 2). Whether this is the onset of spontaneous seizures or some other change remains to be determined.

\section{THERAPEUTIC IMPLICATIONS}

Mossy fiber sprouting is one of the most consistent pathological findings of mTLE, and the recurrent excitatory circuits created by sprouted mossy fiber axons have long held appeal as a mechanism of epileptogenesis. Recent work has provided new insights into the cellular and molecular basis of the phenomenon. First, it is now clear that both developmentally generated and adultgenerated granule cells contribute to mossy fiber sprouting. The specific temporal dynamics of whether, and under what conditions, different age cell populations contribute is still being worked out, but it seems reasonable to conclude that therapies designed to reduce sprouting will need to target granule cells produced from development to adulthood. Second, mTOR pathway activation has emerged as an essential requirement of
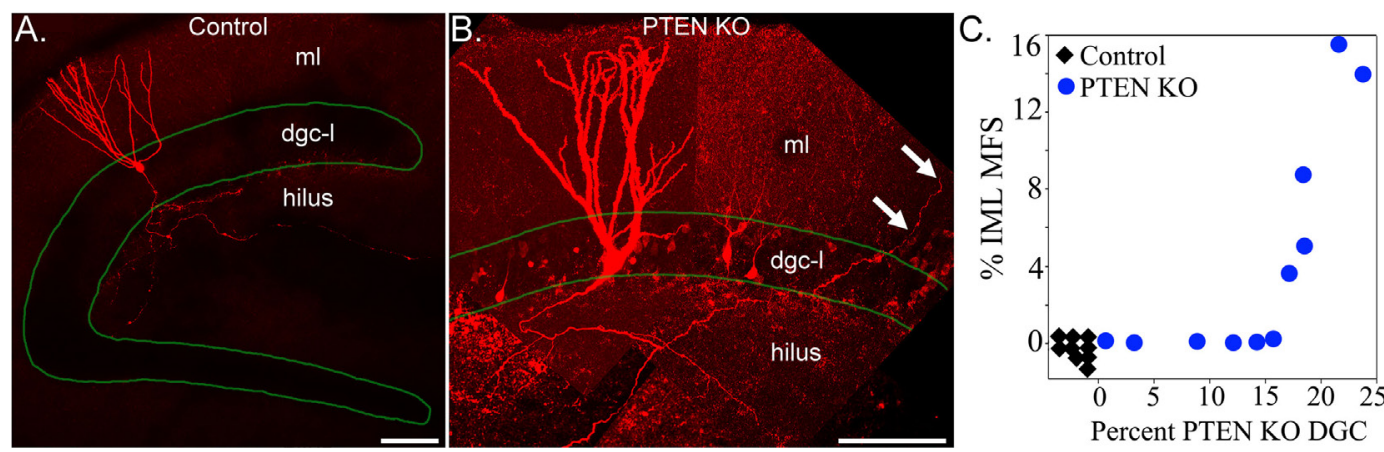

FIGURE 2 | Confocal reconstructions of biocytin-filled hippocampal granule cells from a control (A) and a phosphatase and tensin homolog (PTEN) knockout (B) mouse. Labeled granule cells are shown in red, while the dentate granule cell body layer (dgc-l) borders are outlined in green. Note that the axons of the control cell are confined to the dentate hilus, while the PTEN knockout cell sends an axon collateral into the molecular layer (arrows). ml, dentate molecular layer. Scale bars $=100 \mu \mathrm{m}$. (C) Correlation between the degree of mossy fiber sprouting (mfs), assessed by ZnT3 immunoreactivity in the inner molecular layer (iml), and the percentage of PTEN KO granule cells. PTEN knockout cells and mossy fiber sprouting were absent from control animals $(n=9$, black diamonds). Note the abrupt transition between animals with $<15 \%$ PTEN knockout cells and no sprouting, and animals with deletion rates $>15 \%$ and extensive sprouting. Figure reproduced in part from Pun et al. (89). 
mossy fiber sprouting. With few exceptions (73), studies consistently demonstrate that blocking mTOR signaling prevents mossy fiber sprouting. mTOR hyperactivation by itself, however, does not appear to be sufficient to produce robust mossy fiber sprouting, as demonstrated by the absence of sprouting in some animals with enhanced mTOR signaling induced by PTEN loss. The mTOR pathway, therefore, appears necessary, but not sufficient, for mossy fiber sprouting. Finally, studies using a range of approaches have dissociated the degree of sprouting from seizure incidence. Epilepsy can occur in the absence of sprouting; sprouting can be reduced without impacting seizure incidence; and seizure incidence can be reduced without reducing sprouting. These negative findings, however, are not proof that mossy fiber sprouting is unimportant. Negative findings may reflect variable effects of sprouting in different epilepsy models, or even among patients. Sprouting may play a role in some cases and not others $(32,62)$. It is also possible that the relevance of mossy fiber sprouting is to epilepsy comorbidities rather

\section{REFERENCES}

1. Acsády L, Kamondi A, Sík A, Freund T, Buzsáki G. GABAergic cells are the major postsynaptic targets of mossy fibers in the rat hippocampus. J Neurosci (1998) 18(9):3386-403. doi:10.1523/JNEUROSCI.18-09-03386.1998

2. Blaabjerg M, Zimmer J. The dentate mossy fibers: structural organization, development and plasticity. Prog Brain Res (2007) 163:85-107. doi:10.1016/ S0079-6123(07)63005-2

3. Kohara K, Pignatelli M, Rivest AJ, Jung HY, Kitamura T, Suh J, et al. Cell type-specific genetic and optogenetic tools reveal hippocampal CA2 circuits. Nat Neurosci (2014) 17(2):269-79. doi:10.1038/nn.3614

4. Llorens-Martín M, Jurado-Arjona J, Avila J, Hernández F. Novel connection between newborn granule neurons and the hippocampal CA2 field. Exp Neurol (2015) 263:285-92. doi:10.1016/j.expneurol.2014.10.021

5. Dudek SM, Alexander GM, Farris S. Rediscovering area CA2: unique properties and functions. Nat Rev Neurosci (2016) 17(2):89-102. doi:10.1038/ nrn.2015.22

6. Sutula T, Zhang P, Lynch M, Sayin U, Golarai G, Rod R. Synaptic and axonal remodeling of mossy fibers in the hilus and supragranular region of the dentate gyrus in kainate-treated rats. J Comp Neurol (1998) 390(4):578-94. doi:10.1002/(SICI)1096-9861(19980126)390:4<578::AID-CNE9>3.0.CO;2-Y

7. Holmes GL, Sarkisian M, Ben-Ari Y, Chevassus-Au-Louis N. Mossy fiber sprouting after recurrent seizures during early development in rats. J Comp Neurol(1999) 404(4):537-53. doi:10.1002/(SICI)1096-9861(19990222)404:4< 537::AID-CNE9>3.0.CO;2-\#

8. Cross DJ, Cavazos JE. Synaptic reorganization in subiculum and CA3 after early-life status epilepticus in the kainic acid rat model. Epilepsy Res (2007) 73(2):156-65. doi:10.1016/j.eplepsyres.2006.09.004

9. Danzer SC, He X, Loepke AW, McNamara JO. Structural plasticity of dentate granule cell mossy fibers during the development of limbic epilepsy. Hippocampus (2010) 20(1):113-24. doi:10.1002/hipo.20589

10. McAuliffe JJ, Bronson SL, Hester MS, Murphy BL, Dahlquist-Topalá R, Richards DA, et al. Altered patterning of dentate granule cell mossy fiber inputs onto CA3 pyramidal cells in limbic epilepsy. Hippocampus (2011) 21(1):93-107. doi:10.1002/hipo.20726

11. Althaus AL, Zhang H, Parent JM. Axonal plasticity of age-defined dentate granule cells in a rat model of mesial temporal lobe epilepsy. Neurobiol Dis (2016) 86:187-96. doi:10.1016/j.nbd.2015.11.024

12. Häussler U, Rinas K, Kilias A, Egert U, Haas CA. Mossy fiber sprouting and pyramidal cell dispersion in the hippocampal CA2 region in a mouse model of temporal lobe epilepsy. Hippocampus (2016) 26(5):577-88. doi:10.1002/ hipo.22543

13. Nadler JV, Perry BW, Cotman CW. Selective reinnervation of hippocampal area CA1 and the fascia dentata after destruction of CA3-CA4 afferents with kainic acid. Brain Res (1980) 182(1):1-9. doi:10.1016/0006-8993(80)90825-2 than seizure incidence. People with mTLE and depression, for example, exhibit more sprouting that people with mTLE alone (94). The consistent, pronounced change in hippocampal wiring produced by mossy fiber sprouting almost certainly affects function, therefore, further study of the phenomenon is critical.

\section{AUTHOR CONTRIBUTIONS}

SD and CG: wrote manuscript, conducted literature searches, and prepared figures.

\section{ACKNOWLEDGMENTS}

This work was supported by the National Institute of Neurological Disorders and Stroke (SCD, Awards R01NS065020 and R01NS062806). We would like to thank Keri Kaeding for useful comments on this manuscript.

14. Sutula T, He XX, Cavazos J, Scott G. Synaptic reorganization in the hippocampus induced by abnormal functional activity. Science (1988) 239(4844): 1147-50. doi:10.1126/science. 2449733

15. Sutula T, Cascino G, Cavazos J, Parada I, Ramirez L. Mossy fiber synaptic reorganization in the epileptic human temporal lobe. Ann Neurol (1989) 26(3):321-30. doi:10.1002/ana.410260303

16. Isokawa M, Levesque MF, Babb TL, Engel J Jr. Single mossy fiber axonal systems of human dentate granule cells studied in hippocampal slices from patients with temporal lobe epilepsy. JNeurosci (1993) 13(4):1511-22. doi:10.1523/JNEUROSCI.13-04-01511.1993

17. Franck JE, Pokorny J, Kunkel DD, Schwartzkroin PA. Physiologic and morphologic characteristics of granule cell circuitry in human epileptic hippocampus. Epilepsia (1995) 36(6):543-58. doi:10.1111/j.1528-1157.1995. tb02566.x

18. de Lanerolle NC, Lee TS, Spencer DD. Histopathology of human epilepsy. In: Noebels JL, Avoli M, Rogawski MA, Olsen RW, Delgado-Escueta AV, editors. Jasper's Basic Mechanisms of the Epilepsies [Internet]. Bethesda, MD: National Center for Biotechnology Information (2012). p. 567-93.

19. Witter MP. The perforant path: projections from the entorhinal cortex to the dentate gyrus. Prog Brain Res (2007) 163:43-61. doi:10.1016/S00796123(07)63003-9

20. Sloviter RS, Lømo T. Updating the lamellar hypothesis of hippocampal organization. Front Neural Circuits (2012) 6:102. doi:10.3389/fncir. 2012.00102

21. Ribak CE, Shapiro LA. Ultrastructure and synaptic connectivity of cell types in the adult rat dentate gyrus. Prog Brain Res (2007) 163:155-66. doi:10.1016/ S0079-6123(07)63009-X

22. Scharfman HE. Advances in understanding hilar mossy cells of the dentate gyrus. Cell Tissue Res (2017). doi:10.1007/s00441-017-2750-5

23. Tauck DL, Nadler JV. Evidence of functional mossy fiber sprouting in hippocampal formation of kainic acid-treated rats. J Neurosci (1985) 5(4):1016-22. doi:10.1523/JNEUROSCI.05-04-01016.1985

24. Buckmaster PS. Mossy fiber sprouting in the dentate gyrus. In: Noebels JL, Avoli M, Rogawski MA, Olsen RW, Delgado-Escueta AV, editors. Jasper's Basic Mechanisms of the Epilepsies [Internet]. Bethesda, MD: National Center for Biotechnology Information (2012). p. 611-37.

25. Houser CR, Miyashiro JE, Swartz BE, Walsh GO, Rich JR, DelgadoEscueta AV. Altered patterns of dynorphin immunoreactivity suggest mossy fiber reorganization in human hippocampal epilepsy. J Neurosci (1990) 10(1):267-82. doi:10.1523/JNEUROSCI.10-01-00267.1990

26. Murphy BL, Hofacer RD, Faulkner CN, Loepke AW, Danzer SC. Abnormalities of granule cell dendritic structure are a prominent feature of the intrahippocampal kainic acid model of epilepsy despite reduced postinjury neurogenesis. Epilepsia (2012) 53(5):908-21. doi:10.1111/j.1528-1167. 2012.03463.x 
27. Janz P, Schwaderlapp N, Heining K, Häussler U, Korvink JG, von Elverfeldt D, et al. Early tissue damage and microstructural reorganization predict disease severity in experimental epilepsy. Elife (2017) 6:e25742. doi:10.7554/ eLife. 25742

28. Dudek FE, Staley KJ. The time course and circuit mechanisms of acquired epileptogenesis. In: Noebels JL, Avoli M, Rogawski MA, Olsen RW, DelgadoEscueta AV, editors. Jasper's Basic Mechanism of the Epilepsies [Internet]. Bethesda, MD: National Center for Biotechnology Information (2012). p. 595-610.

29. Proper EA, Jansen GH, van Veelen CW, van Rijen PC, Gispen WH, de Graan PN. A grading system for hippocampal sclerosis based on the degree of hippocampal mossy fiber sprouting. Acta Neuropathol (2001) 101(4):405-9.

30. Schmeiser B, Li J, Brandt A, Zentner J, Doostkam S, Freiman TM. Different mossy fiber sprouting patterns in ILAE hippocampal sclerosis types. Epilepsy Res (2017) 136:115-22. doi:10.1016/j.eplepsyres.2017.08.002

31. Fisher RS, Cross JH, French JA, Hiqurashi N, Hirsch E, Jansen FE, et al. Operational classification of seizure types by the International League Against Epilepsy: position paper of the ILAE commission for classification and terminology. Epilepsia (2017) 58(4):522-30. doi:10.1111/epi.13670

32. Hester MS, Danzer SC. Accumulation of abnormal adult-generated hippocampal granule cells predicts seizure frequency and severity. J Neurosci (2013) 33(21):8926-36. doi:10.1523/JNEUROSCI.5161-12.2013

33. Kempermann G. Adult neurogenesis: an evolutionary perspective. Cold Spring Harb Perspect Biol (2015) 8(2):a018986. doi:10.1101/cshperspect. a018986

34. Eriksson PS, Perfilieva E, Björk-Eriksson T, Alborn AM, Nordborg C, Peterson DA, et al. Neurogenesis in the adult human hippocampus. Nat Med (1998) 4(11):1313-7. doi:10.1038/3305

35. Spalding KL, Bergmann O, Alkass K, Bernard S, Salehpour M, Huttner HB, et al. Dynamics of hippocampal neurogenesis in adult humans. Cell (2013) 153(6):1219-27. doi:10.1016/j.cell.2013.05.002

36. Sorrells SF, Paredes MF, Cebrian-Silla A, Sandoval K, Qi D, Kelley KW, et al. Human hippocampal neurogenesis drops sharply in children to undetectable levels in adults. Nature (2018) 555(7696):377-81. doi:10.1038/nature25975

37. Schmidt-Hieber C, Jonas P, Bischofberger J. Enhanced synaptic plasticity in newly generated granule cells of the adult hippocampus. Nature (2004) 429(6988):184-7. doi:10.1038/nature02553

38. Ge S, Yang C, Hsu K, Ming G, Song H. A critical period for enhanced synaptic plasticity in newly generated neurons of the adult brain. Neuron (2007) 54(4):559-66. doi:10.1016/j.neuron.2007.05.002

39. Gu Y, Arruda-Carvalho M, Wang J, Janoschka SR, Josselyn SA, Frankland PW, et al. Optical controlling reveals time-dependent roles for adult-born dentate granule cells. Nat Neurosci (2012) 12:1700-6. doi:10.1038/nn.3260

40. Nakashiba T, Cushman JD, Pelkey KA, Renaudineau S, Buhl DL, McHugh TJ, et al. Young dentate granule cells mediate pattern separation, whereas old granule cells facilitate pattern completion. Cell (2012) 149(1):188-201. doi:10.1016/j.cell.2012.01.046

41. Parent JM, Yu TW, Leibowitz RT, Geschwind DH, Sloviter RS, Lowenstein DH. Dentate granule cell neurogenesis is increased by seizures and contributes to aberrant network reorganization in the adult rat hippocampus. J Neurosci (1997) 17(10):3727-38. doi:10.1523/JNEUROSCI.17-10-03727.1997

42. Ribak CE, Tran PH, Spigelman I, Okazaki MM, Nadler JV. Status epilepticus-induced hilar basal dendrites on rodent granule cells contribute to recurrent excitatory circuitry. J Comp Neurol (2000) 428(2):240-53. doi:10.1002/1096-9861(20001211)428:2<240::AID-CNE4>3.0.CO;2-Q

43. Walter C, Murphy BL, Pun RYK, Spieles-Engemann AL, Danzer SC. Pilocarpine-induced seizures cause selective time-dependent changes to adult-generated hippocampal dentate granule cells. J Neurosci (2007) 27(28): 7541-52. doi:10.1523/JNEUROSCI.0431-07.2007

44. Kron MM, Zhang H, Parent JM. The developmental stage of dentate granule cells dictates their contribution to seizure-induced plasticity. J Neurosci (2010) 30(6):2051-9. doi:10.1523/JNEUROSCI.5655-09.2010

45. Murphy BL, Pun RYK, Yin H, Faulkner CR, Loepke AW, Danzer SC. Heterogeneous integration of adult-generated granule cells into the epileptic brain. J Neurosci (2011)31(1):105-17. doi:10.1523/JNEUROSCI.2728-10.2011

46. Santos VR, de Castro OW, Pun RYK, Hester MS, Murphy BL, Loepke AW, et al. Contributions of mature granule cells to structural plasticity in temporal lobe epilepsy. Neuroscience (2011) 197:348-57. doi:10.1016/j.neuroscience. 2011.09.034
47. Singh SP, LaSarge CL, An A, McAuliffe JJ, Danzer SC. Clonal analysis of newborn hippocampal dentate granule cell proliferation and development in temporal lobe epilepsy. eNeuro (2016) 2(6):1-13. doi:10.1523/ENEURO. 0087-15.2015

48. Parent JM, Murphy GG. Mechanisms and functional significance of aberrant seizure-induced hippocampal neurogenesis. Epilepsia (1998) 49(Suppl 5): 19-25. doi:10.1111/j.1528-1167.2008.01634.x

49. Danzer SC. Mossy fiber sprouting in the epileptic brain: taking on the Lernaean Hydra. Epilepsy Curr (2017) 17(1):50-1. doi:10.5698/1535-7511-17.1.50

50. Jessberger S, Römer B, Babu H, Kempermann G. Seizures induce proliferation and dispersion of doublecortin-positive hippocampal progenitor cells. Exp Neurol (2005) 196(2):342-51. doi:10.1016/j.expneurol.2005.08.010

51. Parent JM, Elliott RC, Pleasure SJ, Barbaro NM, Lowenstein DH. Aberrant seizure-induced neurogenesis in experimental temporal lobe epilepsy. Ann Neurol (2006) 59(1):81-91. doi:10.1002/ana.20699

52. Shapiro LA, Ribak CE. Newly born dentate granule neurons after pilocarpine-induced epilepsy have hilar basal dendrites with immature synapses. Epilepsy Res (2006) 69(1):53-66. doi:10.1016/j.eplepsyres.2005.12.003

53. Arisi GM, Garcia-Cairasco N. Doublecortin-positive newly born granule cells of hippocampus have abnormal apical dendritic morphology in the pilocarpine model of temporal lobe epilepsy. Brain Res (2007) 1165:126-34. doi:10.1016/j.brainres.2007.06.037

54. Shapiro LA, Figueroa-Aragon S, Ribak CE. Newly generated granule cells show rapid neuroplastic changes in the adult rat dentate gyrus during the first five days following pilocarpine-induced seizures. Eur J Neurosci (2007) 26(3):583-92. doi:10.1111/j.1460-9568.2007.05662.x

55. Koyama R, Tao K, Sasaki T, Ichikawa J, Miyamoto D, Muramatsu R, et al. GABAergic excitation after febrile seizures induces ectopic granule cells and adult epilepsy. Nat Med (2012) 18(8):1271-8. doi:10.1038/nm.2850

56. Hastings NB, Gould E. Rapid extension of axons into the CA3 region by adult-generated granule cells. J Comp Neurol (1999) 413:146-54. doi:10.1002/ (SICI) 1096-9861(19991011)413:1<146::AID-CNE10>3.0.CO;2-B

57. Zhao C, Teng EM, Summers RG Jr, Ming GL, Gage FH. Distinct morphological stages of dentate granule neuron maturation in the adult mouse hippocampus. J Neurosci (2006) 26(1):3-11. doi:10.1523/JNEUROSCI.3648-05.2006

58. Toni N, Laplagne DA, Zhao C, Lombardi G, Ribak CE, Gage FH, et al. Neurons born in the adult dentate gyrus form functional synapses with target cells. Nat Neurosci (2008) 11(8):901-7. doi:10.1038/nn.2156

59. Cho K-O, Lybrand ZR, Ito N, Brulet R, Tafacory F, Zhang L, et al. Aberrant hippocampal neurogenesis contributes to epilepsy and associated cognitive decline. Nat Commun (2015) 6:6606. doi:10.1038/ncomms7606

60. Hosford BE, Liska JP, Danzer SC. Ablation of newly generated hippocampal granule cells has disease-modifying effects in epilepsy. J Neurosci (2016) 36(43):11013-23. doi:10.1523/JNEUROSCI.1371-16.2016

61. Hosford BE, Rowley S, Liska JP, Danzer SC. Ablation of peri-insult generated granule cells after epilepsy onset halts disease progression. Sci Rep (2017) 7(1):18015. doi:10.1038/s41598-017-18237-6

62. Buckmaster PS. Does mossy fiber sprouting give rise to the epileptic state? Adv Exp Med Biol (2014) 813:161-8. doi:10.1007/978-94-017-8914-1_13

63. Sha LZ, Xing XL, Zhang D, Yao Y, Dou WC, Jin LR, et al. Mapping the spatio-temporal pattern of the mammalian target of rapamycin (mTOR) activation in temporal lobe epilepsy. PLoS One (2012) 7(6):e39152. doi:10.1371/ journal.pone.0039152

64. Jeong A, Wong M. Targeting the mammalian target of rapamycin for epileptic encephalopathies and malformations of cortical development. J Child Neurol (2018) 33(1):55-63. doi:10.1177/0883073817696814

65. Talos DM, Jacobs LM, Gourmaud S, Coto CA, Sun H, Lim KC, et al. Mechanistic target of rapamycin complex 1 and 2 in human temporal lobe epilepsy. Ann Neurol (2018) 83(2):311-27. doi:10.1002/ana.25149

66. Zeng L-H, Rensing NR, Wong M. The mammalian target of rapamycin (mTOR) signaling pathway mediates epileptogenesis in a model of temporal lobe epilepsy. J Neurosci (2009) 29(21):6964-72. doi:10.1523/JNEUROSCI. 0066-09.2009

67. Huang X, Zhang H, Yang J, Wu J, McManon J, Lin Y, et al. Pharmacological inhibition of the mammalian target of rapamycin pathway suppresses acquired epilepsy. Neurobiol Dis (2010) 40(1):193-9. doi:10.1016/j.nbd.2010. 05.024

68. van Vliet EA, Forte G, Holdman L, den Burger JC, Sinjewel A, de Vries HE, et al. Inhibition of the mammalian target of rapamycin reduces epileptogenesis 
and blood-brain barrier leakage but not microglia activation. Epilepsia (2012) 53(7):1254-63. doi:10.1111/j.1528-1167.2012.03513.x

69. Guo D, Zeng L, Brody DL, Wong M. Rapamycin attenuates the development of posttraumatic epilepsy in a mouse model of traumatic brain injury. PLoS One (2013) 8(5):e64078. doi:10.1371/journal.pone.0064078

70. Russo E, Citraro R, Donato G, Camastra C, Iuliano R, Cuzzocrea S, et al. mTOR inhibition modulates epileptogenesis, seizures, and depressive behavior in a genetic rat model of absence epilepsy. Neuropharmacology (2013) 69:25-36. doi:10.1016/j.neuropharm.2012.09.019

71. Butler CR, Boychuk JA, Smith BN. Effects of rapamycin treatment on neurogenesis and synaptic reorganization in the dentate gyrus after controlled cortical impact injury in mice. Front Syst Neurosci (2015) 9:163. doi:10.3389/ fnsys.2015.00163

72. Buckmaster PS, Lew FH. Rapamycin suppresses mossy fiber sprouting but not seizure frequency in a mouse model of temporal lobe epilepsy. J Neurosci (2011) 31(6):2337-47. doi:10.1523/JNEUROSCI.4852-10.2011

73. Sliwa A, Plucinska G, Bednarczyk J, Lukasiuk K. Post-treatment with rapamycin does not prevent epileptogenesis in the amygdala stimulation model of temporal lobe epilepsy. Neurosci Lett (2012) 509(2):105-9. doi:10.1016/j. neulet.2011.12.051

74. Heng K, Haney MM, Buckmaster PS. High-dose rapamycin blocks mossy fiber sprouting but not seizures in a mouse model of temporal lobe epilepsy. Epilepsia (2013) 54(9):1535-41. doi:10.1111/epi.12246

75. Shima A, Nitta N, Suzuki F, Laharie AM, Nozaki K, Depaulis A. Activation of mTOR signaling pathway is secondary to neuronal excitability in a mouse model of mesio-temporal lobe epilepsy. Eur J Neurosci (2015) 41(7):976-88. doi:10.1111/ejn.12835

76. Drion CM, Borm LE, Kooijman L, Aronica E, Wadman WJ, Hartog AF, et al. Effects of rapamycin and curcumin treatment on the development of epilepsy after electrically induced status epilepticus in rats. Epilepsia (2016) 57(5):688-97. doi:10.1111/epi.13345

77. Tang H, Long H, Zeng C, Li Y, Bi F, Wang J, et al. Rapamycin suppresses the recurrent excitatory circuits of dentate gyrus in a mouse model of temporal lobe epilepsy. Biochem Biophys Res Commun (2012) 420(1):199-204. doi:10.1016/j.bbrc.2012.02.143

78. Yamawaki R, Thind K, Buckmaster PS. Blockade of excitatory synaptogenesis with proximal dendrites of dentate granule cells following rapamycin treatment in a mouse model of temporal lobe epilepsy. J Comp Neurol (2015) 523(2):281-97. doi:10.1002/cne.23681

79. Hester MS, Hosford BE, Santos VR, Singh SP, Rolle IJ, LaSarge CL, et al. Impact of rapamycin on status epilepticus induced hippocampal pathology and weight gain. Exp Neurol (2016) 280:1-12. doi:10.1016/j.expneurol. 2016.03.015

80. Buckmaster PS, Ingram EA, Wen X. Inhibition of the mammalian target of rapamycin signaling pathway suppresses dentate granule cell axon sprouting in a rodent model of temporal lobe epilepsy. J Neurosci (2009) 29(25):8259-69. doi:10.1523/JNEUROSCI.4179-08.2009

81. Brewster AL, Lugo JN, Patil VV, Lee WL, Qian Y, Vanegas F, et al. Rapamycin reverses status epilepticus-induced memory deficits and dendritic damage. PLoS One (2013) 8(3):e57808. doi:10.1371/journal.pone.0057808

82. Longo BM, Mello LE. Blockade of pilocarpine- or kainate-induced mossy fiber sprouting by cycloheximide does not prevent subsequent epileptogenesis in rats. Neurosci Lett (1997) 226(3):163-6. doi:10.1016/S0304-3940 (97)00267-X
83. Longo BM, Mello LE. Supragranular mossy fiber sprouting is not necessary for spontaneous seizures in the intrahippocampal kainate model of epilepsy in the rat. Epilepsy Res (1998) 32(1-2):172-82. doi:10.1016/S0920-1211 (98)00049-7

84. Bittencourt S, Covolan L, Hamani C, Longo BM, Faria FP, Freymuller E, et al. Replacement of asymmetric synaptic profiles in the molecular layer of dentate gyrus following cycloheximide in the pilocarpine model in rats. Front Psychiatry (2015) 6:157. doi:10.3389/fpsyt.2015.00157

85. Williams PA, Wuarin JP, Dou P, Ferraro DJ, Dudek FE. Reassessment of the effects of cycloheximide on mossy fiber sprouting and epileptogenesis in the pilocarpine model of temporal lobe epilepsy. J Neurophysiol (2002) 88(4):2075-87. doi:10.1152/jn.2002.88.4.2075

86. Toyoda I, Buckmaster PS. Prolonged infusion of cycloheximide does not block mossy fiber sprouting in a model of temporal lobe epilepsy. Epilepsia (2005) 46(7):1017-20. doi:10.1111/j.1528-1167.2005.04605.x

87. Zhu K, Yuan B, Hu M, Feng GF, Liu Y, Liu JX. Reduced abnormal integration of adult-generated granule cells does not attenuate spontaneous recurrent seizures in mice. Epilepsy Res (2017) 133:58-66. doi:10.1016/j. eplepsyres.2017.04.004

88. Amiri A, Cho W, Zhou J, Birnbaum SG, Sinton CM, McKay RM, et al. Pten deletion in adult hippocampal neural stem/progenitor cells causes cellular abnormalities and alters neurogenesis. J Neurosci (2012) 32(17): 5880-90. doi:10.1523/JNEUROSCI.5462-11.2012

89. Pun RY, Rolle IJ, LaSarge CL, Hosford BE, Rosen JM, Uhl JD, et al. Excessive activation hof mTOR in postnatally generated granule cells is sufficient to cause epilepsy. Neuron (2012) 75(6):1022-34. doi:10.1016/j.neuron.2012.08.002

90. Matsushita Y, Sakai Y, Shimmura M, Shigeto H, Nishio M, Akamine S, et al. Hyperactive mTOR signals in the proopiomelanocortin-expressing hippocampal neurons cause age-dependent epilepsy and premature death in mice. Sci Rep (2016) 6:22991. doi:10.1038/srep22991

91. LaSarge CL, Santos VR, Danzer SC. PTEN deletion from adult-generated dentate granule cells disrupts granule cell mossy fiber axon structure. Neurobiol Dis (2015) 75:142-50. doi:10.1016/j.nbd.2014.12.029

92. LaSarge CL, Pun RY, Muntifering MB, Danzer SC. Disrupted hippocampal network physiology following PTEN deletion from newborn dentate granule cells. Neurobiol Dis (2016) 96:105-14. doi:10.1016/j.nbd.2016.09.004

93. Santos VR, Pun RYK, Arafa SR, LaSarge CL, Rowley S, Khademi S, et al. PTEN deletion increases hippocampal granule cell excitability in male and female mice. Neurobiol Dis (2017) 108:339-51. doi:10.1016/j.nbd.2017.08.014

94. Kandratavicius L, Hallak JE, Young LT, Assirati JA, Carlotti CG Jr, Leite JP. Differential aberrant sprouting in temporal lobe epilepsy with psychiatric co-morbidities. Psychiatry Res (2012) 195(3):144-50. doi:10.1016/j.psychres. 2011.06.005

Conflict of Interest Statement: The authors declare that the research was conducted in the absence of any commercial or financial relationships that could be construed as a potential conflict of interest.

Copyright $\odot 2018$ Godale and Danzer. This is an open-access article distributed under the terms of the Creative Commons Attribution License (CC BY). The use, distribution or reproduction in other forums is permitted, provided the original author $(s)$ and the copyright owner are credited and that the original publication in this journal is cited, in accordance with accepted academic practice. No use, distribution or reproduction is permitted which does not comply with these terms. 